\title{
Implementasi Model Pembelajaran Konsiderasi Sebagai Upaya Penanaman Karakter Anak Di RA Al-Washliyah Kisaran Kabupaten Asahan
}

\author{
Mhd. Habibu Rahman \\ Universitas Islam Negeri Sunan Kalijaga \\ Email: habiburahman393@gmail.com
}

\begin{abstract}
Abstrak
Tulisan ini menyajikan tentang penerapan model pembelajaran konsiderasi dan pentingnya penanaman karakter kepada anak sejak usia dini. Model pembelajaran konsiderasi adalah model pembelajaran yang menekankan sikap sebagai hasil belajar serta adanya proses perubahan keyakinan, sikap dan nilai kearah yang lebih baik. Penelitian ini bertujuan untuk mengetahui penerapan model pembelajaran konsiderasi pada anak usia dini, dan Metode apasaja yang digunakan guru untuk menanamkan karakter anak usia dini. Sumber data dalam penelitian ini meliputi kepala sekolah, guru kelas, dan anak. Pengumpulan data dilakukan dengan observasi, wawancara, dan dokumentasi. Analisis data dilakukan dengan reduksi data, penyajian data, dan penarikan kesimpulan. Berdasarkan hasil penelitian dapat disimpulkan bahwa model pembelajaran konsiderasi yang diterapkan di RA AlWashliyah Kisaran Kabupaten Asahan yaitu memperlakukan setiap anak dengan rasa hormat, menjauhi sikap otoriter, menciptakan kebersamaan, saling membantu, saling menghargai. Penanaman karakter menggunakan metode bercerita, bermain peran, keteladanan, dan pembiasaan.
\end{abstract}

Kata Kunci: Karakter anak ; Konsiderasi; Model Pembelajaran

\begin{abstract}
This paper presents the application of the consideration learning model and the importance of planting character to children from an early age. The consideration learning model is a learning model that emphasizes attitudes as a result of learning and the process of changing beliefs, attitudes and values towards a better direction. This study aims to find out the application of the consideration model of learning in early childhood, and what methods are used by teachers to instill the character of early childhood. Sources of data in this study include principals, class teachers, and children. Data collection is done by observation, interviews, and documentation. Data analysis is done by data reduction, data presentation, and conclusion drawing. Based on the results of the study it can be concluded that the consideration learning model applied at RA Al-Washliyah Kisaran Asahan Regency is to treat each child with respect, stay away from authoritarianism, create togetherness, help each other, respect each other. Planting characters using the method of storytelling, role playing, exemplary, and habituation.
\end{abstract}

Keywords: Child Character;Consideration; Learning Model,

\section{PENDAHULUAN}

Pendidikan nasional berfungsi mengembangkan kemampuan dan membentuk watak serta peradaban bangsa yang bermartabat dalam rangka mencerdaskan kehidupan bangsa. Bertujuan untuk mengembangkan potensi anak didik agar menjadi manusia yang beriman dan 
bertaqwa kepada Tuhan Yang Maha Esa, berakhlak mulia, sehat, berilmu, cakap, kreatif, mandiri, menjadi warga Negara yang demokratis serta bertanggung jawab. Belajar adalah suatu proses dimana suatu organisme berubah perilakunya sebagai akibat pengalaman. Belajar merupakan proses orang memperoleh berbagai kecakapan, ketrampilan, dan sikap yang mencerminkan pendidikan. Pendidikan anak usia dini secara mikro merupakan pendidikan yang diberikan kepada anak di luar lingkungan keluarga sebelum memasuki pendidikan dasar. Sedangkan secara makro, pendidikan anak usia dini diawali dari pendidikan keluarga, dilanjutkan playgroup, taman kanak-kanak dan SD hingga kelas dua. (Hibana S. Rahman, 2012:4)

Pemerintah juga sudah memberikan panduan Standar Tingkat Pencapaian Perkembangan Anak (STPPA) dalam Peraturan Menteri Pendidikan dan Kebudayaan Nomor 137 Tahun 2014. Adanya standar ini diharapkan pendidik memberikan kegiatan yang dapat mengasah semua aspek perkembangan anak. Dalam dunia pendidikan, terdapat beberapa macam model pembelajaran. Salah satunya adalah model pembelajaran konsiderasi. Model pembelajaran konsiderasi merupakan model pembelajaran yang menekanakn pada penanaman sikap empati kepada orang lain.

Dari rumusan pendidikan nasional dan definisi belajar di atas, sudah jelas bahwa belajar merupakan suatu kegiatan direncanakan yang kompleks dengan tujuan meningkatkan kualitas dan kuantitas tingkah laku manusia dalam bentuk kognitif, afektif dan psikomotiknya. Namun sangat disayangkan pada kenyataanya pendidikan yang berlangsung di Indonesia hanya menitik beratkan pada peningkatan kualitas kognitifnya saja yang dilaksanakan melalui berbagai bentuk pendekatan, strategi dan model pembelajaran tertentu. Pembelajaran seakan mengabaikan kualitas pembentukkan kemampuan afektif serta psikomotor si pembelajar. Hal ini dibuktikan dengan penelitian pendahuluan yang dilakukan di beberapa RA di Kabupaten Asahan. Dari penelitian pendahuluan ini didapatkan bahwa adanya tuntutan dari wali murid agar anaknya bisa membaca, menulis, dan berhitung untuk persiapan masuk sekolah dasar sehingga pembelajaran di sekolah lebih fokus untuk kognitif anak, sedangkan aspek pengembangan sikap kurang diperhatikan, sehingga berdampak pada karakter setiap anak yang bersifat individual, kurang empati dan peduli terhadap sesama.

Berdasarkan latar belakang di atas maka peneliti tertarik untuk melakukan penelitian di RAAl-Washliyah Kisaran Kabupaten Asahan untuk mengetahui implementasi model pembelajaran konsiderasi pada pendidikan anak usia dini.

Model pembelajaran konsiderasi pertama kali dicetuskan oleh Peter Mc Phail yang bekerjasama dengan School Council Project dalam pendidikan moral Inggris. Phail yang merupakan seorang humanis menentang keras pendidikan pada waktu itu yang menerapkan pendidikan moral dengan sangat rasional dan kognitif. Beliau berpendapat bahwa moralitas lebih bersifat sebagai gaya kepribadian, bukan gaya berfikir. Model pembelajaran ini mengembangkan sejumlah materi pendidikan moral untuk memelihara kepekaan peserta didik terhadap kebutuhan dan perasaan orang lain. (John P. Miller, 2002:189) Dalam penelitiannya terhadap 800 siswa menengah pertama, dihasilkan bahwa kebutuhan manusia yang paling penting adalah bergaul dengan baik dengan orang lain, untuk mencintai dan 
dicintai. Asumsi yang mendasari John P. Miller berdasarkan pendapat Dani Rahmadani (2005:90-91) antara lain:

1. Pendidikan moral harus memperhatikan kepribadian setiap orang.

2. Model pembelajaran ini menekanakn pada ranah afektif.

3. Model pembelajaran ini menggunakan cara yang non-indoktrinatif.

4. Terdapat dua bidang dalam diri manusia, yaitu rasional dan sikap.

5. Orang dewasa merupakan model bagi peserta didik. Peserta didik lebih banyak belajar moralitas dari bagaimana guru berperilaku dari pada apa yang diajarkannya.

Manusia seringkali bersifat egoistis, lebih memperhatikan, mementingkan dan sibuk mengurus dirinya sendiri. Pembelajaran etika/moral bertujuan untuk membantu siswa agar mempedulikan dan mengindahkan orang lain, memperhatikan perasaan dan pribadi orang lain. (Yusri Pangabean, 2007:84) Kebutuhan yang fundamnetal pada manusia adalah bergaul secara harmonis dengan orang lain, saling memberi dan saling menerima dengan penuh cinta kasih dan kasih sayang. Oleh sebab itu, model ini menekankan kepada strategi pembelajaran yang dapat membentuk kepribadian. Tujuannya adalah agar siswa menjadi manusia yang memiliki kepedulian terhadap orang lain sehingga mereka dapat bergaul, bekerjasama, hidup secara harmonis dengan orang lain, dan dapat merasakan apa yang dirasakan orang lain. Dengan demikian, pembelajaran sikap pada dasarnya adalah membantu anak agar dapat mengembangkan kemampuan untuk bisa hidup bersama seca harmonis, peduli, dan merasakan apa yang dirasakan oleh orang lain. (Hamruni, 2009:189) Dalam kehidupannya orang berpedoman pada nilai-nilai sebagai standar bagi segala aktivitasnya. Nilai-nilai ini ada yang tersembunyi dan adapula yang dapat dinyatakan secara eksplisit. Nilai juga bersifat multidimensional, relatif dan absolut. Model pembentukan rasional bertujuan mengembangkan kematangan pemikiran tentang nilai-nilai.

Model konsiderasi dapat digolongkan kedalam rumpun model kepedulian moral yang melibatkan emosi dan empati terhadap orang lain. Memiliki sikap peduli terhadap sesama dalam mengembangkan pembelajaran dan belajar bekerjasama dalam memecahkan sebuah permasalahan. Pola pembelajaran yang menerapkan rasa kepedulian diharapkan anak-anak belajar untuk memahami dan saling membantu dalam kehidupanya. Orang yang mampu menempatkan rasa peduli terhadap sesama akan dipedulikan dan dihargai oleh sesamanya.

Konsep model pembelajaran konsiderasi ini sendiri merupakan model pembelajaran yang berbasis pada humanis yakni bertujuan membuat siswa atau anak-anak belajar dengan memahami dan menghargai orang lain sebagai wujud pembentukan masyarakat yang humanis dan harmonis. Dalam proses belajar menggunakan model belajar konsiderasi tidak hanya aspek kognitif yang dikembangkan, namun ada tiga kelompok aspek/ komponen yang harus diintegrasikan dalam proses pembelajaran. Ketiga komponen tersebut diuraikan dalam Ikhwan Luthfi (2009:60-61) sebagai Komponen kognitif berisi persepsi, kepercayaan dan stereotype yang dimiliki individu mengenai 
sesuatu. Seringkali komponen kognitif ini dapat disamakan dengan pandangan (opini) terutama apabila menyangkut masalah isu atau problem yang kontroversia, Komponen afektif merupakan perasaan individu terhadap objek sikap dan menyangkut masalah emosi., dan Komponen ini berisi tendensi atau kecenderungan untuk bertindak atau untuk bereaksi terhadap sesuatu dengan cara tertentu. Komponen konatif merupan kecenderungan berperilaku tentu sesuai dengan sikap yang dimiliki oleh seseorang.

Model pembelajaran konsiderasi merupakan salah satu model pembelajaran yang menekankan sikap sebagai hasil belajar. Model ini termasuk salah satu model dari pendidikan nilai. Pendidikan nilai merupakan proses perubahan keyakinan, sikap dan nilai kearah yang lebih baik. Sehingga proses pendidikan ini memunculkan sisi afektif yang meliputi ketiga komponen yakni: kognisi (kecerdasan), afeksi (perasaan), dan psikomotorik (perbuatan).

Konsiderasi erat kaitannya dengan pendidikan nilai yang dimaksudkan untuk membantu peserta didik agar memahami, menyadari dan mengalami nilai-nilai serta mampu menempatkanya secara integral dalam kehidupan. Dalam proses pendidikan nilai tindakan-tindakan pendidikan yang lebih spesifik dimaksudkan untuk mencapai tujuan yang lebih khusus. Seperti dikemukakan komite APEID (Asia and The Pasific Programe of Educational Innovation for Development) dalam Moh. Muslih (2007:35) bahwa pendidikan nilai secara khusus ditujukan untuk: (a) menerapkan pembentukan nilai pada anak, (b) menghasilkan sikap yang mencerminkan nilai-nilai yang diinginkan, (c) membimbing perilaku anak-anak.

Model pembelajaran konsiderasi merupakan pembelajaran pada sikap empati. Empati berasal dari bahasa Yunani "phatos" yang berarti perasaan yang mendalam. Empati berhubungan dengan bagaimana orang lain merasakan diri saya. (Asri Budiningsih, 2004:46) Oleh sebab itu empati merupakan kemampuan seseorang dalam memahami perasaan orang lain, mampu menempatkan diri seolah-olah berada dalam keadaan orang lain, serta mampu mengontrol sikap. Kemampuan ini harus dibiasakan sejak dini, supaya anak dapat terlatih untuk merasakan apa yang dialami oleh orang lain.

Berempati tidak hanya dilakukan dalam bentuk memahami perasaan orang lain, tetapi juga tercermin dalam perkataan dan sikap. Gazda dalam Akhmad (2013:48) memaparkan bahwa terdapat tiga tahapan dalam berempati, yaitu: Tahap pertama, mendengarkan dengan seksama apa yang diceritakan orang lain, bagaimana perasaannya, dan apa yang terjadi pada dirinya; Tahap kedua, menyusun kata-kata untuk menggambarkan perasaan dan situasi tersebut; Tahap ketiga, menggunakan susunan kata tersebut untuk mengenali orang lain dan berusaha memahami perasaan serta situasinya.

Beberapa tahapan yang dikemukakan Gazda dalam Akhmad dapat dibiasakan dilatih pada anak sejak usia dini. Anak dalam satu kelas bisa jadi memiliki tahapan yang berbeda-beda. Hal ini disebabkan karena kemampuan anak dalam menyerap pelajaran berbeda-beda. Selain itu, pengaruh lingkungan keluarga juga ikut berpengaruh dalam 
pencapaian tahapan berempati anak. Sikap seseorang merupakan implementasi dari emosi, hati dan mental seseorang yang terlihat dalam perilaku setiap harinya. Jika perasaan seseorang terhadap sesuatu positif maka akan terpancar pula perilaku positif dari individu bersangkutan dalam menyikapi sesuatu yang dihadapi seseorang itu dan sebaliknya. (Inge Hutagalung, 2007:51) Pembentukan sikap pada anak-anak sangat penting dilakukan sejak dini agar mereka tumbuh dengan bekal sikap saling menghargai dan mampu berinteraksi serta menyikapi sesuatu dengan sikap positif mereka.

Model pembelajaran konsiderasi ini juga seperti model pembelajaran yang lainnya memiliki kelebihan dan kekurangan. Berdasarkan beberapa teori yang telah diuraikan, maka dapat diketahui bahwa model pembelajaran konsiderasi ini sesuai dengan penelitian Nur Salim dalam Jurnal efektor (2010) memiliki beberapa kelebihan, antara lain: Menghadapkan siswa pada situasi nyata, sehingga siswa dapat terlibat secara aktif; Melatih siswa untuk berpikir dan berperasaan secara obyektif dan adil; Dapat meningkatkan kesiapan hubungan antar pribadi. Model ini dapat melatih siswa untuk menganalisis situasi. Siswa yang sudah terbiasa menggunakan pembelajaran konsiderasi dapat mengetahui perasaan orang lain tanpa menanyakannya terlebih dahulu, sehingga peserta didik dapat menempatkan diri dengan baik; Peserta didik terlatih untuk membedakan mana yang baik dan mana yang buruk; Peserta didik terbiasa untuk berperilaku sesuai dengan norma-norma; dan Peserta didik terbiasa untuk berbagi. Sehingga jika model ini diterapkan secara serius, maka kesejahteraan akan dapat tercapai.

Selain beberapa kelebihan yang telah diungkapkan di atas, model pembelajaran konsiderasi ini juga tidak luput dari beberapa kekurangan, sesuai dengan penelitian Nur Salim dalam Jurnal efektor (2010) yaitu:Tidak dapat diterapkan pada semua standar kompetensi. Model ini kurang cocok untuk tujuan yang tergolong dalam pemberian pengetahuan (kognitif), Sulitnya melakukan kontrol karena banyak faktor yang mempengaruhi perkembangan sikap seseorang, Keberhasilan pembentukan sikap tidak bisa dievaluasi dengan segera, karena perubahan sikap dapat dilihat dalam retang waktu yang cukup lama.

\section{METODE PENELITIAN}

Berdasarkan jenis data yang digunakan dan tujuan penelitian yang akan dicapai, Metode yang digunakan dalam penelitian ini adalah metode deskriptif, pendekatan yang digunakan dalam penelitian ini adalah pendekatan kualitatif. Lokasi dalam penelitian ini adalah di RA Al-Washliyah Kisaran Kabupaten Asahan. Subjek dalam penelitian ini kepala sekolah, guru, dan siswa di RA Al-Washliyah Kisaran Kabupaten Asahan. Penelitian dilaksanakan pada bulan Februari-Maret 2019. 
Instrumen penelitian dalam penelitian ini digunakan tiga jenis instrumen yaitu Instrumen observasi untuk mengamati cara guru mengembangkan metode berkisah dalam pembelajaran. Observasi yaitu tekhnik pengumpulan data dimana peneliti mengadakan pengamatan langsung gejala-gejala subyek yang diteliti. (Lexi. J. Moleong, 2002: 126), Instrumen wawancara digunakan pada guru untuk mendapatkan informasi lebih rinci terhadap metode pembelajaran yang digunakan guru. Wawancara merupakan proses memperoleh keterangan dengan cara tanya jawab sambil bertatap muka dengan menggunakan pedoman wawancara. (Imron Arifin, 1996: 69)

\section{HASIL DAN PEMBAHASAN}

\section{Hasil penelitian}

Berdasarkan penelitian yang telah dilakukan, diperoleh sebuah gambaran tentang implementasi model pembelajaran konsiderasi dan penanaman karakter anak di RA AlWashliyah Kisaran Kabupaten Asahan, bahwa guru melakukan beberapa tahapan diantaranya: Guru memberikan informasi kepada anak-anak tentang rencana pembelajaran menggunakan model konsiderasi; Guru menjelaskan pada anak-anak maksud dan tujuan pembelajaran dengan konsiderasi sehingga anak-anak dapat memahami dan menjalankan pembelajaran konsiderasi ini dengan baik; Memberikan durasi waktu pelaksanaan pembelajaran agar waktu yang dipakai lebih bisa dikondisikan; Memberikan aturan main pada anak-anak selama kegiatan pembelajaran konsiderasi dengan kegiatan main yang disajikan; Guru berupaya semaksimal mungkin untuk menjadi contoh dan memberikan contoh di dalam kelas dengan memperlakukan setiap anak dengan rasa hormat, menjauhi sikap otoriter, menciptakan kebersamaan, saling membantu, saling menghargai, dan lain sebagainya.

Pembelajaran konsiderasi di RA Al-Washliyah Kisaran Kabupaten Asahan dilaksanakan melalui kegiatan bercerita islami yang dilakukan setiap pagi disaat masuk kelas. Selain itu, model pembelajaran yang menggunakan sentra, dimanfaatkan oleh pendidik untuk memaksimalkan pendidikan konsiderasi pada saat sentra Iman dan Taqwa (IMTAQ) dan sentra bermain peran. Pada saat sentra IMTAQ dan bermain peran, kegiatan yang dilakukan guru adalah bercerita kisah-kisah islami dan anak didik diajak untuk menghayati cerita yang dibacakan guru serta tokoh yang diperankan.

Berdasarkan hasil wawancara dengan kepala sekolah, diperoleh data bahwa para pendidik juga dihimbau untuk selalu menjadi contoh dan memberikan teladan yang baik bagi anak baik ketika di sekolah maupun di luar sekolah. Semua wali murid juga di ajak bersamasama untuk menjadi contoh dan memberikan teladan pada anak. Nilai-nilai islami yang diajarkan guru dari pembelajaran konsiderasi yaitu dengan membiasakan anak untuk mengantri disaat berwudhu, menyirami tanaman, menghibur teman yang bersedih, menghargai hasil karya teman, membantu guru ketika membawa barang, membuang sampah pada tempatnya, meminta maaf ketika bersalah, dan mengucapkan tolong ketika memerlukan bantuan. 


\section{Pembahasan}

Salah satu karakter yang diperoleh dari model pembelajaran konsiderasi adalah rasa empati. Sebenarnya rasa empati sudah ada pada anak sejak lahir. Hal ini dibuktikan ketika ada bayi yang menangis, bayi yang lain juga ikut menangis. Adapun rasa empati yang perlu dikembangkan pada anak sejak dini yaitu: (1) Empati kepada sesama manusia. Sejak dini anak dididik untuk ikut merasakan apa yang dirasakan orang lain. Dengan demikian pada diri anak akan tumbuh sifat kasih sayang, adil, bijaksana, dan sopan santun kepada orang lain; (2) Empati kepada binatang. Rasa empati kepada makhluk lain juga harus ditanamkan pada anak. Anak yang memiliki rasa empati pada binatang, maka akan tumbuh pada diri anak bahwa binatang juga harus disayangi seperti halnya manusia, (3) Empati kepada tumbuh-tumbuhan. Sejak dini anak diajarkan bahwa tumbuhan memiliki banyak manfaat untuk manusia. Seperti memberikan udara yang sehat dan segar, mengurangi pencemaran udara, dan menyimpan air. Oleh sebab itu, anak diajarkan untuk merasakan bahwa tumbuhan juga harus dipelihara dan ; (4) Empati kepada lingkungan. Rasa empati terhadap lingkungan dapat diwujudkan seperti tidak mencoret-coret tembok. Anak usia dini perlu ditanamkan bahwa lingkungan juga harus dijaga kebersihan dan keindahannya.

Adapun metode yang dapat digunakan dari model pembelajaran konsiderasi sehingga dapat menanamkan karakter pada anak usia dini yaitu: (1) Bercerita. Bercerita merupakan kegiatan mengkhayal yang dapat mengembangkan rasa empati anak. Karena pada kegiatan ini, anak dapat membayangkan dan merasakan apa yang dirasakan oleh orang lain; (2) Bermain peran. Bermain peran merupakan kegiatan bermain yang menggunakan daya khayal anak dengan berpura-pura memperagakan suatu tokoh. Kegiatan ini dapat membangun rasa empati anak karena dengan kegiatan ini anak dapat menyelami perasaan orang lain tanpa ikut larut di dalamnya; (3) Keteladanan. Menjadi teladan dan memberikan keteladanan menjadi salah satu metode paling ampuh untuk menanamkan karakter yang baik pada anak. Karakter yang baik harus tertanam terlebih dulu dalam diri guru dan orangtua. Sehingga tidak merasa berat dalam memberikan teladan;dan (4) Pembiasaan. Yaitu membiasakan anak sejak dini untuk berperilaku empati seperti mengisi kotak amal, mengucapkan tiga kata ajaib "maaf, tolong, terima kasih".

\section{KESIMPULAN DAN SARAN}

\section{Kesimpulan}

Berdasarkan hasil penelitian, maka dapat disimpulkan bahwa implementasi model pembelajaran konsiderasi dan penanaman karakter pada anak di RA Al-Washliyah Kisaran Kabupaten asahan sebagai berikut: Model pembelajaran konsiderasi merupakan model pembelajaran yang berfokus pada penanaman sikap dan karakter pada anak. Metode yang digunakan untuk menerapkan model ini adalah metode pembiasaan dan keteladanan. Penerapan model pembelajaran konsiderasi ini memiliki beberapa kelebihan, antara lain menghadapkan siswa pada situasi nyata, mengasah sikap empati anak, anak dapat 
membedakan perilaku baik dan buruk. Selain kelebihan, model pembelajaran ini juga memiliki beberapa kekurangan, antara lain tidak semua standar kompetensi cocok menggunakan model konsiderasi dan keberhasilan model pembelajaran ini tidak dapat dilihat dalam waktu yang singkat. Penanaman karakter kepada anak melalui model pembelajaran konsiderasi di RA Al-Washliyah Kisaran diimplementasikan melalui berbagai metode seperti bercerita, bermain peran, keteladanan, dan pembiasaan. Anak yang sudah memiliki karakter yang baik dapat tercermin dalam perilakunya yang suka menolong, meminta ijin sebelum meminjam, mau mengantri, mau meminta maaf, dan berterima kasih.

\section{Saran}

Dari hasil penelitian yang berkaitan dengan implementasi model pembelajaran konsiderasi sebagai upaya penanaman karakter pada anak usia dini di RA Al-Washliyah Kisaran, dapat disampaikan saran-saran sebagai berikut:Bagi pimpinan lembaga RA Al-Washliyah Kisaran, hendaknya pimpinan lembaga RA lebih menghimbau guru-guru untuk lebih efektif dan variatif dalam mengadakan kegiatan bermain peran dan kegiatan bercerita kisah islami. Bagi guru, hendaknya guru selalu memberikan telaadan dan menjadi teladan yang baik untuk anak, lebih variatif dalam penggunaan model pembelajaran konsiderasi. Bagi orangtua, hendaknya orangtua menerapkan pola asuh demokratis dan menajdi teladan bagi anak.

\section{DAFTAR PUSTAKA}

Arifin, Imron. (1996). Penelitian Kualitatif. Malang: Kalimasada Press.

Azzet, Akhmad Muhaimin. (2013). Urgensi Pendidikan Karakter di Indonesia. Yogyakarta: Ar Ruzz Media.

Budiningsih, Asri. (2004). Pembelajaran Moral. Jakarta: Rineka Cipta.

Hamruni. (2009). Strategi dan Model-Model Pembelajaran Aktif dan Menyenangkan. Yogyakarta: Fakultas Ilmu Tarbiyah dan keguruan UIN Sunan Kalijaga.

Hutagalung, Inge. (2007). Pengembangan Kepribadian. Jakarta: Indeks.

Ikhwan Luthfi, dkk. (2009). Psikologi Sosial. Jakarta: Lembaga Penelitian UIN Jakarta.

Miller, John P. (2002). Cerdas di Kelas Sekolah Kepribadian, Yogyakarta: Kreasi Wacana.

Moleong, Lexy J. (2012). Metodologi Penelitian Kualitatif. Bandung: Remaja Rosdakarya.

Muslih, Moh. Strategi Pendidikan Nilai Moral. Forum Tarbiyah Vol. 5, No, 1 Juni 2007.

Pangabean, Yusri, dkk. (2007). Strategi, model dan Evaluasi. Bandung: Bina Media Informasi.

Rahmadani, Dani. (2005). Implementasi Pendidikan Nilai dalam Mata Kuliah dasar Umum. Disertasi Pascasrajana UPI.

Rahman, Hibana S. (2012). Konsep Dasar Pendidikan Anak Usia Dini. Yogyakarta: Galah.

Salim, Nur. (2010). Pengaruh Penerapan Model Pembelajaran Konsiderasi Terhadap Sikap Tenggang Rasa. Jurnal Efektor No. 16, April. 